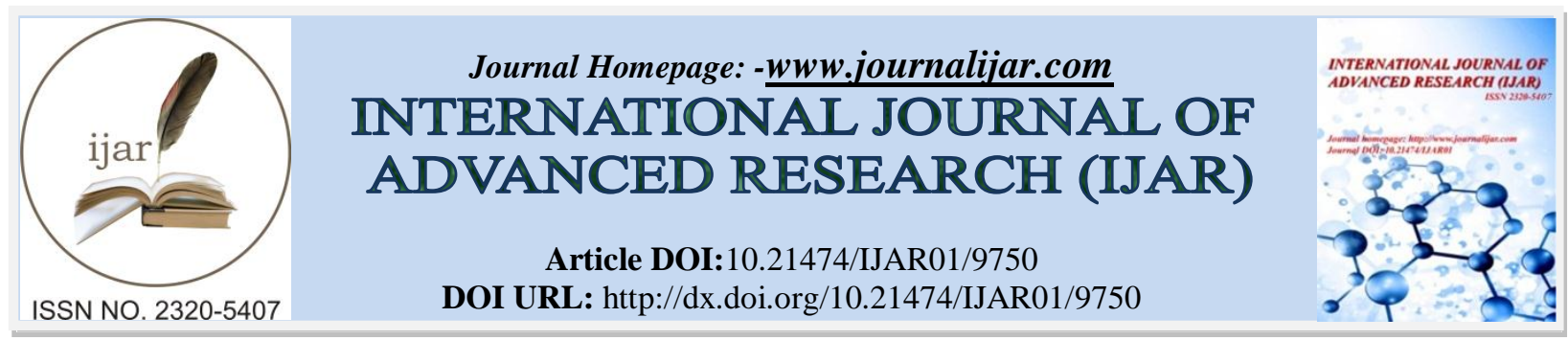

RESEARCH ARTICLE

\title{
PANACEA FOR EDUCATIONAL PRIMITIVENESS OF MUSLIMS IN INDIA.
}

Dr.AnsariZartabJabeen.

Faculty- Maulana Azad College of Arts Science and Commerce \& visiting faculty of Department of P.G.Studies in law Dr.BabasahebAmbedkar MarathwadaUnivesity, Aurangabad Maharashtra.

\section{Manuscript Info}

Manuscript History

Received: 12 July 2019

Final Accepted: 14 August 2019

Published: September 2019

Key words:-

Education Backwardness Religion obligation.

\section{Abstract}

Education is the backbone of civilised nation it has the potential of transforming an individual, communities, societies and the nation at large. Yet, it is ironical that it is not explored to its fullest potential in India especially among Muslim minorities. The Educational backwardness of the Muslim community in India has been recognized and tinted by a number of officials report such as the Gopal Singh Minority Panel Report; Ranganath Mishra Commission report and Sachhar committee as well as Mehmood-ur-rehman committee. Seeking Knowledge is obligatory on Muslims as per their Religious principles irrespective of gender; but still Muslims have failed to perform their religious obligation in India. The Right to education is secured even by constitutional provisions especially with respect to minorities in India, but despite it Muslims have not benefitted in educational matters. Though other minorities co-exist in India but other than Muslims no other minority is educationally backward as per official reports.

The present article reflects the importance of education from religious perspectives; it further puts forth constitutional and statutory provisions ensuring right to education in India. It highlights the educational status of Muslims in India in the light of various reports of committees and annual reports submitted by the officials. The article concludes with strong suggestions to uplift Muslims from educational backwardness.

Copy Right, IJAR, 2019,. All rights reserved.

\section{Introduction:-}

Education is the key factor in development of the nation as it is a recognised legal right in India despite that there is educational backwardness among the largest minority community.

\section{Aim}

The present research aims to find out why the Muslim community is educationally backward despite their religious obligation and fundamental rights guaranteed to them under the constitutional provisions.

\section{Objectives:-}

1. To study the religious obligations pertaining to knowledge and education.

2. To study the Statutory and constitutional provisions with respect to educational rights of minorities

Corresponding Author:-Dr.AnsariZartabJabeen.

Address:-Faculty Department of P.G.Studies in law MarathwadaUnivesity. 
3. To understand the causes of educational backwardness among Muslim minority community.

\section{Researchable Questions}

Q1. What are the religious obligation of Muslims with respect to attainment of knowledge and education?

Q2. Despite religious obligations and rights pertaining to education why there is educational backwardness among Muslims?

\section{Research Methodology:-}

The present research is non-empirical in nature, and analytical approach is adopted. The research being nonempirical is carried on with the help of secondary data available in the form of religious texts, books, journal articles, magazines, reports of various committees and official reports etc.

"Knowledge is power. Information is liberating. Education is the premise of progress, in every society, in every family."

Kofi Annan ${ }^{1}$

Approximately after seventy years of Independence India is still under the category of developing nations and not developed nation. India being democratic nation is obliged to protect the rights of minorities. The constitution of India ensures the religious as well as linguistic minorities certain rights with respect to their educational institutions; in spite of it the educational backwardness of Muslims cannot be denied. The gloomy picture of Muslim educational backwardness is portrayed by various committees' reports. The government had launched various schemes for ameliorating the economic and educational condition of Muslims which have remained merely on papers and were unsuccessful in achieving the desired goals.

\section{Religious Obligations on Muslims with respect to education and knowledge}

The first word revealed to our Prophet Muhammad (Peace Be upon Him) from Allah SWT was "Iqra" which means to Read! To seek knowledge! Educate yourselves! Be Educated. As our Prophet (PBUH) said "TalabUl Ilmu Farizatun Ala Kulli Muslim". Acquiring knowledge is obligatory on every Muslim, the Knowledge of Truth and Wisdom.

To seek knowledge is a sacred duty; it is obligatory on every Muslim, male and female. "Iqra Biismi RabbikaAllazi Khalq". Read! In the name of your Lord who created (all the exists) ${ }^{2}$.

The Holy Prophet (blessings and peace be upon him) said: "TalibulilmiFaridata ala kulli Muslim" meaning "Acquisition of knowledge is binding on all Muslims (both men and women without any discrimination)"

The Prophet Muhammad (SAW) encouraged all Muslims to acquire knowledge and share it. He said:"Acquire knowledge, for he who acquires it in the way of Allah performs an act of piety; he who speaks of it, praises the Lord; he who seeks it, adores Allah; he who dispenses instruction in it, bestows alms; and he who imparts it to others, performs an act of devotion to Allah. ${ }^{4 "}$

\section{Madarsa (Islamic seminary) Education in Islam and India}

Holy Prophet (pbuh) gained victory over his foes at the battle of Badr ${ }^{5}$, in which 70 people of the enemy rank were imprisoned and these prisoners were literate people. In order to seek benefit from their education of these prisoners the Prophet declared that if one prisoner teaches 10 Muslim children how to read and write, it will serve as his ransom and he will be set free. This is how the foundation of the first school in the history of Islam was laid down by the Prophet himself with all its teachers being non-Muslims ${ }^{6}$. For many historians the contributions from the

1 Former Secretary General of U.N.O

2 Surah Al'Alaq 96:1

3[Narrated by Ibn Maja in al-Sunan, 1:81 §224.]

4Bukhari, Muslim

$5624 \mathrm{CE}$

6 Walter S. Saul, "Seeking knowledge is one of the central tenets of Islam", September 9, 2011

http://bermudasun.bm/Content/NEWS/News/Article/Seeking-knowledge-is-one-of-the-central-tenets-of-

Islam/24/270/54120 Aug 152019 3:01 P.M IST 
Islamic world have had a considerable effect on the development of Western civilization and contributed to the achievements of the Renaissance. ${ }^{7}$

Madarsa, system of imparting knowledge can be traced to early 10th century in Iran as an institution where any one of the four schools of religion in Islam - the madhhab - along with Arabic grammar, the traditions of the Prophet hadith, history, literature, rhetoric, mathematics, an and astronomy are taught. The establishment of the current model of the Madarsa can be traced to NizamulMulk (c. 1018-92). With the advent of Britishers in India the diminution of the syllabi of Madarsas was made and they introduced modern educational institutions. After the 1857 war, the language of the courts was changed from Persian to English. The Muslim elites who were trained at home and in Madarsas in the "classical" subjects were loathe joining the English grammar schools ${ }^{8}$. For Muslim parents and religious scholars the first priority for their children is the acquisition of knowledge about Islam and their religious beliefs ${ }^{9}$. In India Muslims sought education from Madarsa ${ }^{10}$; they were the centers of free education; and also played a vital role in spreading literacy amongst the down trodden segments of Muslim society. Even today several Madarsas offer free education as well as free boarding \& lodging. ${ }^{11}$ The Madarsa education in India makes education for all possible instead of restricting it for only elite section of the society. There were only 88 Madarsa in India. Their number rose to 5 lakhs in 2006 and their present number is far higher ${ }^{12}$.

\section{Educational Rights of minorities under Indian constitution}

Article 29 (1) of the Indian Constitution provides to any section of the citizens living in any part of the country having different language, script or culture of its own, should have the right to conserve their language, script or culture.

Article 29(2), states that citizens belonging to different religion, race, caste, language or any of them, shall not be disallowed to take admission into any educational institution which is under the supervision of the State or getting help out of State funds on the basis of religion, race, caste, language or any of them.

Article 30 (1) provides/assures the right to establish or bring into existence educational institutions of their personal choice and to administer or effectively manage and conduct the affairs of those institutions.

Article 30 (2) restricts a State from discriminating any type of minority section on the grounds of religion or language in the matter of providing help to any educational institutions run by them.

\section{National Policy of education- 1986 and in its Programme of Action (1990)}

Several provisions concerning education of minorities were incorporated in the National Policy of education- 1986 and in its Programme of Action (1990), stress was laid on minority education especially Muslims as they are largest minority of the largest democracy. Propositions were made to design varied kind of programs and schemes for modification of the Madarsa curriculum, minority education and its development ${ }^{13}$.

\section{Right to Education Act, 2009}

The act aims at providing free and compulsory education to every child above the age of six years and below the age of fourteen years.

7.Lebedel, "Without contacts with the Arab culture, Renaissance couldprobably not have happened in the 15th and 16th century", , p. 109

8. M.J.Warsi, "Madarsa education in India: Need for modern approach", ,June 18, 2015

https://www.deccanherald.com/content/484170/madarsa-education-india-need-modern.html

9R.Ohri, "Galloping Growth of Madrasas in India", http://indiafacts.org/galloping-growth-madrasas-india/Aug 15

2019 5:32 P.M IST

10 An exclusivisttheologicalIslamicseminary, or a religiousschool, wherechildren are initiatedintotenets of the

Quran, the Sharia and Hadith

11 https://unbeatenknight.wordpress.com/2015/07/14/madarsas-their-importance-in-society/ Aug 15 2019 3:17P.M

12Devendra Mittal, 'Hindusthan Mein Madarasey' (Hindi), p.64

13Campus Journo "Educational Status of Muslims In India: Problems \& Prospects" October 9,

2018https://thecompanion.in/educational-status-of-muslims-in-india-problems-prospects/ August 82019 10:40 P...M

IST 


\section{Gopal Singh Minority Panel Report on Educational backwardness among Muslims}

Gopal Singh Committee in its report ${ }^{14}$ maintained that there was a "sense of discrimination prevailing among the minorities" and that it "must be eliminated, root and branch, if we want the minorities to form an effective part of the mainstream." 15 This Committee identified Muslims and Neo-Buddhists as two educationally backward minorities at the national level and proposed special efforts for bringing them at par with the rest of the society. ${ }^{16}$

\section{Sachhar committee on Educational backwardness of Muslims}

The Report has also drawn attention to the low levels of educational attainment among Muslim women, Muslims in rural areas as well as in technical and higher education. The High Level Committee under the Chairmanship of Justice Rajinder Sachar has also made a number of recommendations for improvement of the educational status of the Muslim communities. ${ }^{17}$

\section{Statistics of educational backwardness among Muslims}

As per the Census Report 2001, the percentages of minority population, viz. Muslims, Christians, Sikhs, Buddhists and Zoroastrians (Parsis) and their literacy rates are, as under:

\begin{tabular}{|l|l|l|}
\hline Communities & Percentage of population & Percentage of literacy \\
\hline Muslims & 12.4 & 59.1 \\
\hline Christians & 2.3 & 80.3 \\
\hline Sikhs & 1.9 & 69.4 \\
\hline Buddhists & 0.8 & 72.7 \\
\hline Zoroastrians (Parsis) & 0.007 & 97.9 \\
\hline
\end{tabular}

Soure: https://mhrd.gov.in/educational-development-minorities

According to Sachhar committee report ${ }^{18}$ the overall literary rate in India has been around $74 \%$ for quite some time, the literary rate of Muslims is around $60 \%$. The data later falls down with the increase in the level even at the high school level due to drop out scenario. In general, 26\% of those aged 17 years and above have completed matriculation; this percentage is only 17\% amongst Muslims."One-fourth of Muslim children in the age group of 614 years has either never attended school or is drop-outs. For children above the age of 17 years, the educational attainment of Muslims at matriculation is $17 \%$, as against national average at $26 \%$. Only $50 \%$ of Muslims who complete middle school are likely to complete secondary education, compared to $62 \%$ at national level".

As per the 2011 Census of India on educational level by religious community and gender has shown that $42.7 \%$ of Muslims in India are illiterate. This is the highest illiteracy rate for any single religious community in the country, while the illiteracy rate for the entire population taken together is $36.9 \% .^{19}$

According to the data of All India survey on Higher Education ${ }^{20}$, Muslim student ratio was only $4.9-5.0 \%$ in 2017-18 in proportion to their population of 14\%. This meager number points to their lack of representation. Community representation among teachers is also nothing short of bad representation. There are only $4.9 \%$ teachers from the community in the higher education.

\section{Schemes for Minority education in India}

The Government of India is running the following Schemes for the improvement of Educational and Economic lot of the Minorities:

\footnotetext{
${ }^{14}$ June 14, 1983

15 M.A.Salam, "The struggle beyond committees and commissions", June 3,

2012http://twocircles.net/2012jun03/struggle_beyond_committees_and_commissions.html Aug 15 2019 4:06 P.M

IST

${ }^{16}$ Minorityyouth association of India, April 132016 ,

https://www.facebook.com/Minority0Youth0Association0of0India/posts/gopal-singh-commission-high-powerpanel-under-the-chairmanship-of-dr-gopal-singh/1687727968157481/ Aug 15 2019 4:18 P.M IST

${ }^{17}$ SachharCommittee Report 2006

182006

${ }^{19}$ https://indianexpress.com/article/india/india-news-india/muslim-illiteracy-rate-india-census-report-education3006798/ Aug 152019 4:43 P.M IST

${ }^{20} \mathrm{http}$ ://aishe.gov.in/aishe/helpOnUniversity
} 
1. Central Sponsored Scheme for Providing Quality Education in Madarsa (SPQEM)

2. Scheme for Infrastructure Development Private Aided/Unaided Minority Institutes (IDMI) - (Elementary Secondary/Senior Secondary Schools)

3. Strengthening of the National Council for Promotion of Urdu Language (NCPUL)

4. Establishment of the National Commission for Minority Educational Institutions (NCMEI) National Commission for Minority Educational Institutions Act, 2004.This act was passed in year 2004 for giving more teeth to minority education in India. This act allows direct affiliation of minority educational institutes to central universities. This act was enacted in order to provide quality education in minority institutes.

5. In addition, Scholarship/Fellowship Schemes and Multi-Sectoral Development Programmes (MSDP) are being implemented by Ministry of Minority Affairs

\section{Maulana Azad National Fellowships for Minorities}

It is strongly urged that, this Fellowship Scheme must be implemented with increased budget at par catering at least 3000 minority students each year for M.Phil. \& Ph.D

\section{National Overseas Scholarship Scheme for Minorities}

National Overseas Scholarship (Karnataka Model) should be implemented so that minority students can also go abroad for better, advanced educational and professional courses and research (Rs. 20 Lakh to each student) ${ }^{21}$.

\section{Causes of Educational backwardness of Muslims}

Ignorance of The Prophet's advice of learning oneself and teaching others as a religious obligation is the root cause of educational backwardness among Muslims. The evil role played by Muslim clerics with the help of the Muslim rulers, to confine learning to only old religious sayings is another reason for educational backwardness of Muslims $^{22}$. The most conservative wing of Indian Islam has typically rested on the education system provided by the hundreds of religious training institutes (madrasas) throughout the country, which have tended to stress the study of the Quran and Islamic texts in Arabic and Persian, and have focused little on modern managerial and technical skills. ${ }^{23}$ Apart from this in modern day times there are several other factors which are responsible for educational backwardness among Muslims in India.

The "communal" content of school curriculum compels Muslims from seeking admissions in schools. Organisations such as VidyaBharatiAkhilBharatiyaShikshaSansthan, predominantly follows a syllabus enshrined with communal overtones. VidyaBharati(Apex Body established in 1977), has the ultimate objective to "develop a National System of Education which would help to build a generation of young men and women that is committed to Hindutva and infused with patriotic fervor". In 1996, NCERT evaluated textbooks of VidyaBharati and found that they were "designed to promote bigotry and religious fanaticism in the name of inculcating knowledge of culture in the young generation" ${ }^{24}$.Hence Muslim parents prefer Madarsas as the only available option.

According to report of Sachhar committee only 4\% (approx) of Muslim children attend Madarsa. Hamid Ansari ${ }^{25}$, in his famous speech ${ }^{26}$ criticised them for being trapped in vicious circle and culturally defensive posture that hinder self-advancement. He stressed on multiple factors responsible for the educational backwardness of Muslims in India, ranging from poverty to lack of political will and government's indifference towards the education of Muslims. Both internal factors like reluctance towards modern education and external factors like acute shortage of schools and colleges in Muslims concentrated localities and improper and no implementation of government schemes in some

21 Campus Journo "Educational Status of Muslims In India: Problems \& Prospects" October 9, 2018 https://thecompanion.in/educational-status-of-muslims-in-india-problems-prospects/ August 82019 10:40 P..M IST 22 C.Mishra, "Basic Causes of Muslim Backwardness", June 2 2007, Mainstream, Vol XLV No https://www.mainstreamweekly.net/article146.html 24 Aug 17 2019 3:09P.M IST 23 Library of Congress http://factsanddetails.com/india/Minorities_Castes_and_Regions_in_India/sub7_4b/entry4193.html Aug 15 2019 5:57 P.M IST

24 V. Ramakrishnan, "Communalism in school curriculum via SanghParivaar'sIndianreforms" frontlinefeb 11 2012, https://communalism.blogspot.com/2012/02/communalism-in-school-curriculum-via.html Accessed on Aug 172019 2:52 P.M IST

25India'sex-president

26 Vice President Hamid Ansari at the Inauguration of GoldenJubilee Session of 'All IndiaMuslimMajlis-e-

Mushawarat' 31-August-2015 12:44 IST Available on http://pib.gov.in/newsite/PrintRelease.aspx?relid=126472. 
states are leading them to double marginalization. ${ }^{27}$ Muslims cannot afford to send their wards to modern schools; and tend to ignore religious obligation of seeking knowledge as well. According to Siddiqui ${ }^{28}$, education is a state subject; and funds meant for education have to be routed through the state minority welfare board to the district minority welfare officer but the process is infected with corruption .Any individual dressing like Muslim approaches department for funds with a Madarsa receipt book and by bribing the government officials absconds with the money; Many so-called madrasas exist only on papers. ${ }^{29}$

Some Muslims think that because of Hindus they are being discriminated against. ${ }^{30}$ Discrimination in securing salaried jobs makes the Muslims more frustrated and they attach less importance to formal 'secular' education in comparison to other Socio-Religious Communities. ${ }^{31}$

Commercialisation of education is a big hurdle in educational empowerment of Muslims. Poverty is another reason of educational backwardness among Muslims. According to a World Bank report in 2013; nearly 34 percent of all Muslims in urban India were below the poverty line compared to 19 per cent of Hindus. Between 1983 and 2009-10, the poverty rate for urban Hindus declined by 52 percent, but the rate of decline for urban Muslims was only at 39 percent. ${ }^{32}$

Rising communalism in India in which the educated The Muslim students are being arrested and labeled as terrorists pushing them behind bars without trial is one of the reason of educational and economic backwardness of Muslims in India. ${ }^{33}$

\section{Facts And figures}

Islam, in its early days till the coming of the Industrial Revolution in Europe, was advanced in Philosophy, Mathematics, Architecture, Space Study, Medicine etc. and Europe used to learn these things from the Arabs. ${ }^{34}$ It is rather unfortunate that Muslims who follow Islam religion have become educationally backward in India; due to one or the other reason. Despite constitutional mandate and guidelines given by judiciary through several cases ${ }^{35}$ the present Government's regime had discriminated against and harassed many minority educational institutions ${ }^{36}$ EknathKhadse ${ }^{37}$, said that, "Madrasas focusing only on studying Islam will now be regarded as "nonschools"."Madrasas are giving students education on religion and not giving them formal education. Our Constitution says every child has the right to take formal education, which Madarsas do not provide," the minister said $^{38}$.

In northern India the average enrollment of Muslims in Non-minority universities is around 1-3\%, average enrollment of Muslims in JamiaMilliaIslamia is 50\% and 75\% in Aligarh Muslim University. ${ }^{39}$ Central Government is deliberately opposing the Minority status due to it is prejudiced and biased perception.

27 A. Ahmed, "On Educational Backwardness of Muslims : Need of AA \& Wake Up Call From Community Leaders", November 28, 2017https://thecompanion.in/educational-backwardness-muslims-need-aa-wake-callcommunity-leaders/ Aug 152019 5:19 P.M IST

28 Chairman of the National Commission of MinorityEducational Institutions (NCMEI), told IANS in an interview. 29F. Ahmed, "Maulvis in IndiaKeepingMuslimsBackward",https://www.boloji.com/articles/6674/maulvis-inindia-keeping-muslims-backward Aug 182019 1:13 A.M IST

30 Supra Note 21

31F.N.Ansari, "Minority Education | A study of Indian Muslims", Vol. 4 No. 1 (2016) Issue- March ISSN 23476869 (E) \& ISSN 2347-2146 (P) Page No. 52-60

32 M.Qazi, "Muslim Anxieties And India's Future” Oct 172018 https://countercurrents.org/2018/10/muslimanxieties-and-indias-future Aug 172019 3:49 P.M IST

33 W.Ali, "The roots of backwardness", GK Magzine https://www.greaterkashmir.com/news/gk-magazine/theroots-of-backwardness/ Aug 182019 1:22 P.M IST

34 Supra note 23

35ManagingBoard, M.T.M v. State of Bihar (AIR 1984 SC 1757)

36 http://www.eurac.edu/Press/Publications/Monographs/0059701.htm

37 The state'sminority'saffairsminister

38 https://www.aljazeera.com/news/2015/07/indian-state-derecognises-madrassa-education-150702141231360.html Aug 152019 5:43 P.M IST

39 (Source: IndianMuslims and Higher Education: A Study of Select Universities in North and South India). 
Centre for Educational Research \& Training (CERT) studied 34 universities of India in which 63,325 Muslim students are pursuing their education out of total 9,15,806 students. It is noticed that as per the data of All India survey on Higher Education ${ }^{40}$, Muslim student ratio was only 4.9\% in 2016-17; vast section of Muslim populace remains illiterate due to lack of facilities for primary and secondary education.

Vastanvi's university, the JamiaIslamiaIshaatulUloom, has 200,000 students on its rolls in schools across India. It has 15 colleges equipped with modern facilities and running engineering, medicine, teaching, pharmacy, and information technology courses. The Madarsa runs schools in Gujarat and Maharashtra and also has 30 hospitals. ${ }^{41}$ West Bengal has become the first state to begin the modernization of the traditional Madrasas with the support from central government. As a result nearly 600 government-recognized Madrasas have modern curricula. They offer courses in physics, chemistry, biology, geography, mathematics, computer science, English language and literature, and other regular subjects. Islamic studies and the Arabic language course form a small part of the curriculum. Interestingly, 15 percent of students in these Madarsa are non-Muslims. ${ }^{42}$ Mumbai's century and a half old IdareAnjuman-Islam; hundreds of similar educational institutions exist all over the country. However, till today they have remained largely bereft of the resources and help that are provided by the government. ${ }^{43}$ Darrussalam Educational Trust; is a self financing minority institution under the founder chairmanship of Late Alhaj Sultan SalahuddinOwaisi (Member of Parliament) is imparting education.

The government's entire focus is the "modernization" of madrasas; without any concrete measures other than doling out a computer set to one madrasas or some random teaching equipment to another. The core concern for the minorities that is the availability of proper formal education is neglected by the government. ${ }^{44}$ Madrasas in several states like UP have modernized their curriculum; several non-profit coaching institutes are pitching in to help create tomorrow's doctors, engineers and civil servants ${ }^{45}$.

\section{Conclusion and suggestions:-}

Seeking education is a religious obligation for Muslims and at the same time it is a constitutional and legal right. Muslims are ignorant of their religious obligations. Though Government has taking certain initiatives through various schemes for uplifting the minorities from educational backwardness but the apathy is that most of the schemes have remained merely on paper due to half hearted attempts of Government. Establishment of educational institutions by Muslims serves the national interest but ironically government instead of promoting the same is trying to remove minority status of educational institutions like Aligarh Muslim University and JamiaMiliaIslamia. Education ministers are making remarks of de-recognizing Madarsas as Schools.

Madrasas, like those run by Vastanvi, can play a imperative role in providing secular and religious education to Muslim minority and uplift them. Madarsa are allies in India's fight against extremism; they help in fulfilling religious obligations and the modernized touch with inclusion of subjects other than religious scriptures will help in removing the taboo of backwardness among Muslims. A great awakening is needed among Muslims they should foster to realise their religious obligations towards education, the present educational status of Muslims should serve as a wakeup call for Muslims. There is need of educated Muslims to form organisations and inspire other Muslims towards educational empowerment.

Government should set up benchmark to define the modernization of Madarsa and both religious and formal education hand in hand will prove to be reformative.

40https://mhrd.gov.in/sites/upload_files/mhrd/files/.../AISHE2011-12P_1.pdf

41 M.Qazi, "India's Emerging Modern Madrasas", March 16, 2017 https://thediplomat.com/2017/03/indiasemerging-modern-madrasas/ Aug 152019 5:54 P.M IST

42 The Hindu, June 22012

43 S.Dalvi, "Some Issues of Muslim Religious Schools in India”, Economic and political weekly Journal » Vol. 50, Issue No. 32, 08 Aug, 2015 https://www.epw.in/journal/2015/32/web-exclusives/some-issues-muslim-religiousschools-india.html Aug 172019 5:22 P.M IST

44 Ibid

45K.Desai\&D.Sanghvi, "Hafiz to IAS: How madrassa students are cracking civils" May 5, 2019, 11:18 IST "http://timesofindia.indiatimes.com/articleshow/69181932.cms?utm_source=contentofinterest\&utm_medium=text\& utm_campaign=cppst Aug 172019 5:14 P.M IST 
"Modernisation" of Madrassas has become a regular catch-phrase for governments, yet there has been negligence in meeting the educational needs of the Muslim minority. It is high time that Muslim institutions and intellectuals come together to work out Madrassa modernisation which meets the needs of the community."

Shirin Dalvi ${ }^{46}$.

${ }^{46}$ Journalist and former editor of the Mumbai edition of Awadhnama, an Urdu daily 